$\xi_{p}=$

\title{
Conservation status of amniotes found in and around Balapur Pond of District Prayagraj (Uttar Pradesh), India
}

\author{
Ashok Kumar Verma* \\ Department of Zoology, Government Post Graduate College, Saidabad Prayagraj-221508 (Uttar Pradesh), India \\ *Corresponding author E-mail:akv.gdcz@gmail.com
}

\begin{abstract}
Perennial Balapur Pond was surveyed and studied to assess the conservation status of reptiles, birds and mammals naturally occurring in and around it. The survey was conducted from January 2018 to June 2019. During entire survey, a total of 7 species of reptiles, 11 species of birds and 8 species of mammals were identified. Among reptilian species reported, 1 species comes under NT (near threatened), 1 species LC (least concern) while 5 species have no special status (NSS). One avian species was CR (critically endangered), one NT (near threatened) and 9 bird species were LC (least concern). Out of 8 mammalian species recorded, one was EN (endangered), one VU (vulnerable) and remaining $6 \mathrm{LC}$ (least concern).Most of the avian and mammalian species are lacking conducive ambience and hunted for food.
\end{abstract}

Keywords: Balapur Pond; Conservation status; Reptiles; Birds; Mammals; Red List.

\section{Introduction}

Chordata is the highly evolved phylum among all animal phyla. These are characterized by the presence of dorsal tubular nerve cord, notochord and pharyngeal gill slits. The chordata is divided into lower chordata and higher chordata. The higher chordata is represented by a single subphylum Vertebrata in which notochord is replaced by vertebral column. The Vertebrates have ventral muscular cardiac system bearing 2-4 chambers. A vertebrate has notochord during its embryonic development which is replaced by a cartilaginous or bony vertebral column called as backbone in adults. Taxonomically higher chordates belong to a subphylum Vertebrata that includes seven classes of living animals viz. Cyclostomata, Chondrichthyes, Osteichthyes, Amphibia, Reptilia, Aves and Mammalia. Last three are popularly known as higher vertebrates or so called amniotes.

Reptiles are also poikilothermic animals with monocondylic skull. These were the first exclusively terrestrial vertebrates with crawling or creeping mode of locomotion. In general the class Reptilia comprises four orders viz. Chelonia (turtle and tortoise), Rhynchocephalia (tuatara), Squamata (lizarda and snakes) and Crocodilia (crocodiles). They are the first amniotes of the earth.

Birds (Aves) also referred to as masters of air, are homoiothermic or warm-blooded egg-laying vertebrates characterized by feathers and forelimbs modified as wings for flight. Jaw bones are prolonged into a toothless beak to serves like hands and mouth concurrently. Mammals are warm-blooded i.e. homoiothermic vertebrates having the skin more or less covered with hair; young are born alive (viviparous) except for the small subclass of monotremes (most primitive mammals comprising the only extant members of the subclass Prototheria) and nourished with milk, having dicondylic skull and a muscular diaphragm. Presence of mammary glands is the most unique feature of this group. The class Mammalia includes egg laying mammals (Prototheria), pouched mammals (Metatheria) and higher viviparous mammals (Eutheria).

Pond is an example of aquatic ecosystem. Wetland is in fact a land transitional between terrestrial and aquatic ecosystem, where the water level is usually at or near the surface or the land is covered by shallow water. Wetlands are very productive ecosystems, which help in the regulation of biological cycles, maintenance of water quality, nutrient movement and support for food chains. Now wetlands are shrinking rapidly because of urbanization and industrialization. Due to urbanization and anthropogenic pressure most of the wetlands are succumbed to greater degree of biologically active nutrient accumulation (Verma and Prakash, 2018a).

\section{Historical Preview}

India is a developing and agriculture dominating nation. Its most of population depend upon agriculture. In India, a number of ponds, lakes and reservoirs are naturally found but they are not being utilized properly due to lack of insufficient study of their hydrobiology. The study of different water parameters is very important for understanding of the metabolic events in the aquatic ecosystem. One of the most important features of ponds is the presence of standing water, which provides habitat for wetland plants and animals.

Wetlands constitute one of the most productive ecosystems and play a significant role in the regional ecological sustainability. They have been an essential part of human civilization meeting many crucial needs for life such as drinking water, food, fodder, energy supply, 
flood storage, transport, recreation, biodiversity, and climate stabilization. The cross cultural, economic and ecological values of wetlands provide a fine blend of past, present and future of human descend, existence, and future perspectives of sustainability.

Pond water is useful both for sustainable and unsustainable agriculture during ancient times. The unsustainable agriculture has multiple effects (Verma 2017a) and disturbs the ecological balance (Verma 2018a).Aquatic ecosystem maintains the ecological, social and economic functions that interconnect the organisms including humans. It is helpful in maintaining the biodiversity. The biodiversity has values (Verma 2016a) and explored at three levels namely: ecosystem diversity, species diversity and genetic diversity. The genetic diversity acts as a buffer for biodiversity (Verma, 2017b). The biodiversity helps to maintain the ecological balance. There is a necessity of ecological balance for widespread biodiversity (Verma 2017c) and the biodiversity loss has ecological impact (Kumar Ajay et al., 2017). The ecological balance is an indispensable need for human survival (Verma 2018b). The climate change has a huge impact on biodiversity (Prakash et al., 2019) and farmers' practices (Mandal et al., 2020).

Prakash et al., (2015a, 2015b, 2015c and 2016a) and Verma et al., (2016a, 2016b and 2020) performed the limnological and ichthyological studies of Alwara Lake of Kaushambi (U.P.) while Verma et al., (2017a, 2017b and 2018a) and Prakash et al., (2017, 2019a and $2019 \mathrm{~b}$ ) studied the fresh water bodies for distribution and conservation of fishes, other chordates and other properties. Verma (2016b, 2016c, 2016d, 2016e, 2017d, 2017e, 2018c, 2019a, 2019b, 2019c and 2020), Ranjan and Prakash (2019) and Prakash (2020a and 2020b) and Prakash et al., (2020) studied the limnological parameters as well as biodiversity and conservation status of fishes in the various lentic and lotic fresh water bodies of Uttar Pradesh. Verma (2018d), Verma et al., (2015, 2016c, 2016d, 2018ba, 2018c and 2019) and Prakash et al., (2016b, 2016c, 2016d, 2019c) studied the Indian sarus crane from various point of views and narrated an increase in its population in Kaushambi district of Uttar Pradesh, India while Wahied et al., (2020) studied the house sparrow and common myna in Doda region of India.Singh et al., (2019) and Yasmeen et al., (2020) studied the arthropod diversity in Indian prospective.

The present survey is undertaken to assess the conservation status of amniotes found in and around Balapur Pond of District Prayagraj (Uttar Pradesh), India.This survey was conducted from January 2018 to June 2019.

\section{Study Area}

Balapur pond is a natural pond, located on south side of the village. It is located in Koraon block and tahsil of Prayagraj district of Uttar Pradesh (fig. 1), India. The pond studied is approximately $62 \mathrm{KM}$ away from District head quarter Prayagraj and $272 \mathrm{KM}$ from State capital Lucknow. This village is surrounded by Janakpur in east, Paitiha in south west, Banshipur in north east and Murlipur in south. The month of March marks the beginning of summer and it lasts till June. Monsoon generally starts in the month of July and lasts till September. December to February is the winter season in and around this village. This pond (fig. 2) is extended in more than two hectaresand is surrounded by agricultural fields from three sides.

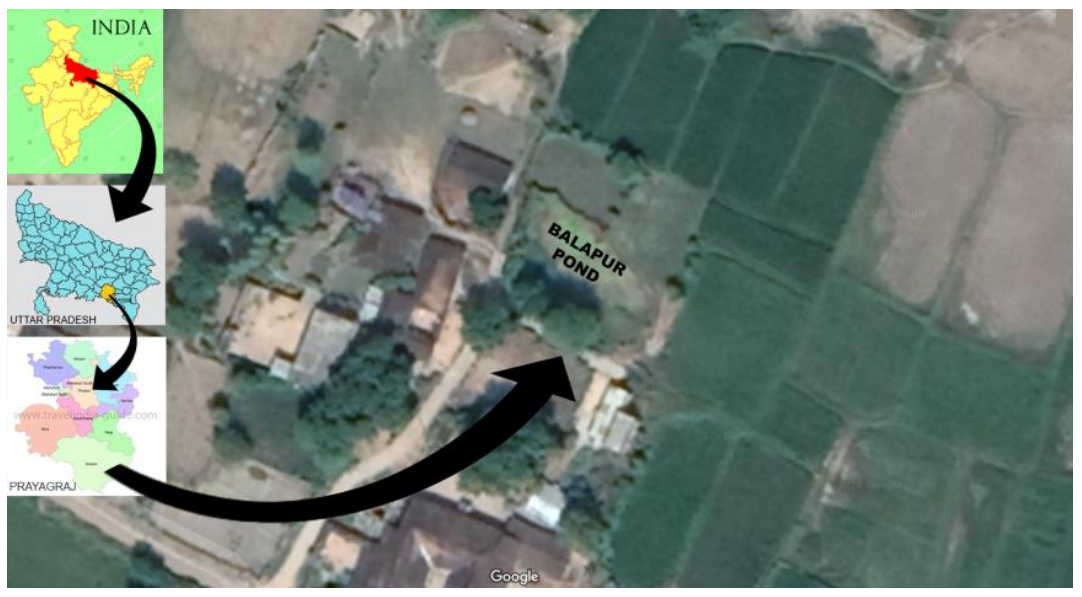

Fig. 1: Location of Study Area of Balapur Pond in Prayagraj District, India.

\section{Materials and Methods}

The perennial Balapur Pond and surrounding area was surveyed and studied in detail to assess the conservation status of different species of amniotes as per IUCN Red List. This study was done once for a month along the period from January 2018 to June 2019 . For field work, standard survey method of Burbridge (1994) was followed. The reptiles were identified with the help of Aengals (2012) while birds were identified with the help of Ali (1988). Author did not need to collect the reptiles, birds and mammals as they were easily recognisable even from a long distance. People of local communities of adjoining areas also helped the author in several ways including hospitality; collection and identification of animals. 


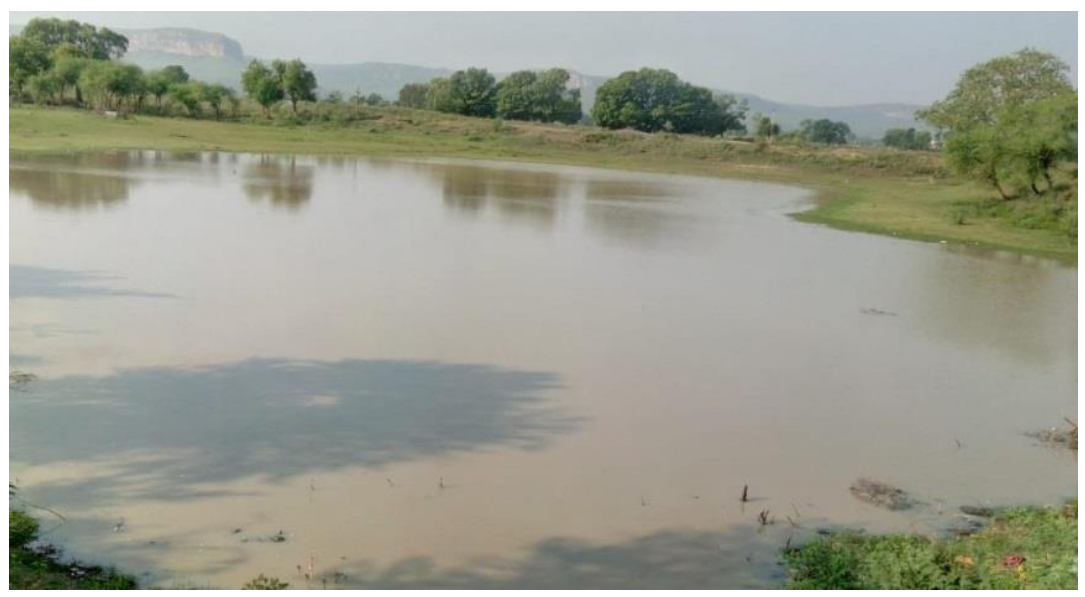

Fig. 2: A View of Balapur Pond in Prayagraj District, India.

\section{Results and Discussion}

The author recorded (1) 7 species of reptiles, (2) 11 species of birds and (3) 8 species of mammals in and around the Balapur pond. The identified species of different amniotes including their common names, zoological names, families, orders and conservation status are shown in Table 1, 2and 3 respectively.

Table 1: List of Reptiles Reported from Balapur duringthe Year 2018-2019

\begin{tabular}{lllll}
\hline S. No. & Common Name & Zoological name & Family & Order \\
\hline 1 & Indian Garden lizard & Calotes versicolor & Agamidae & Squamata \\
2 & The spiny tailed lizard & Uromastixhardwickii & Agamidae & Squamata \\
3 & House gecko & Hemidactylus flaviviridis & Gekkonide & Squamata \\
4 & The Indian Cobra & Najanaja & Elapidae & Squamata \\
5 & Krait & Bungarus caeruleus & Elapidae & NSS \\
6 & Red Sand Boa & Eryxjohnii & Boidae & NSS \\
7 & Indian Monitor lizard & Varanus bengalensis & Squamata & Squamata \\
\hline
\end{tabular}

Table 2: List of Birds Reported from Balapur duringthe Year 2018-2019

\begin{tabular}{lllll}
\multicolumn{7}{c}{ Table 2: List of Birds Reported from Balapur duringthe Year 2018-2019 } \\
\hline S. No. & Common Name & Zoological name & Family & Order \\
\hline 1 & Peacock & Pavocristatus & Phasianidae & Galliformes \\
2 & Koel & Eudynamisscolopaceus & Cuculidae & Cuculiformes \\
3 & Common myna & Acriodotherestristis & Sturnidae & Passeriformes \\
4 & House Sparrow & Passer domesticus & Passeridae & Passeriformes \\
5 & House Crow & Corvussplendens & Corvidae & Passeriformes \\
6 & Red-vented Bulbul & Pycnonotuscafer & Pycnonidae & Passeriformes \\
7 & Parrot & Psittaculaeupatria & Psittaculidae & Psittaciformes \\
8 & Common Rock Pigeon & Columba livia & Columbidae & Columbiformes \\
9 & Owl & Bubo bubo & Strigidae & Strigiformes \\
10 & Indian Vulture & Gyps indicus & Accipitridae & Accipitriformes \\
11 & Indian Egret & Egrettagarzetta & Ardeidae & LC \\
\hline
\end{tabular}

Table 3:List of Mammals Reported from Balapur during the Year 2018-2019

\begin{tabular}{lllll}
\hline S.No. & Common Name & Zoological name & Family & Order \\
\hline 1 & The Rabbit & Oryctolagus cuniculus & Leporidae & Lagomorpha \\
2 & Shrew & Sorexaraneus & Soricidae & Eulipotyphla \\
3 & Rat & Rattus rattus & Muridae & Rodentia \\
4 & House mouse & Mus musculus & Muridae & Rodentia \\
5 & Squirrel & Funambulus palmarum & Sciuridae & Rodentia \\
6 & Pig & Sus scrofa & Suidae & Artiodactyla \\
7 & Nilgai & Boselaphustragocamelus & Bovidae & Artiodactyla \\
8 & Smooth-coated Otter & Lutrogaleperspicillata & Mustelidae & Carnivora \\
\hline
\end{tabular}

$[\mathrm{NSS}=$ no special status, $\mathrm{NE}=$ not evaluated, $\mathrm{LC}=$ least concern, $\mathrm{NT}=$ near threatened, $\mathrm{VU}=$ vulnerable, EN= endangered and $\mathrm{CR}=\mathrm{critically}$ endangered $]$.

On the basis of rate of decline, population size, area of geographic distribution and degree of population, distribution fragmentation etc., IUCN (International Union for Conservation of Nature) Red List (2020) classified the species into nine groups.These are EX (extinct), EW (extinct in wild), CR (critically endangered), EN (endangered), VU (vulnerable), NT (near threatened), LC (least concern), DD (data deficient) and NE (not evaluated). When discussing the IUCN Red List, the official terms "threatened" is a grouping of 3 categories: Critically Endangered, Endangered and Vulnerable. Among reptilian species reported, 1 species was under NT, 1 species LC while 5 species had no special status (NSS). One avian species was CR, one NT and 9 bird species were LC. Out of 8 mammalian species recorded, one was EN, one VU and remaining 6 LC.

\section{Conclusion}

The author thus, recorded 7 species of reptiles, 11 species of birds and 8 species of mammals in and around the Balapur pond of Prayagraj district, Uttar Pradesh, India. Out of 26 species recorded, one species was CR, one EN, one VU, two NT and 16 LC while 5 
had no special status. Most of the avian and mammalian species are lacking a suitable habitat and appropriate places for reproduction. They are often hunted for food. The author recommends a complete survey of entire village from biodiversity and conservation point of view.

\section{Acknowledgement}

Author is highly grateful to the Prof. Ashish Joshi, Principal, Government P.G. College, Saidabad- Prayagraj (U.P.) for providing necessary laboratory facilities. Author is also obliged to senior colleague Dr Shri Prakash, youngster Mr Prabhakar Singh, local people and Gram Pradhan for their full co-operation during entire survey programme.

\section{References}

[1] Aengals R., Kumar V.M.S. and Palot M. J. (2012). Updated Checklist of Indian Reptiles.

[2] Ali S. (1998). The Book of Indian Birds. Oxford University Press, India.

[3] Burbridge R. R. (1994). Integrated planning and management of fresh water habitats including wetlands. J. hydrobiol. 285 (1-3): 311-322. https://doi.org/10.1007/BF00005678.

[4] IUCN (2020). The IUCN Red List of Threatened Species. Version 2020-1. https://www.iucnredlist.org. Downloaded on 19 March 2020.

[5] Kumar Ajay and Verma A.K. (2017). Biodiversity loss and its Ecological impact in India.International Journal on Biological Sciences. 8(2): 156160 .

[6] Mandal A.C. and Singh O.P. (2020). Climate Change and Practices of Farmers' to maintain rice yield: A case study. International Journal of Biological Innovations. 2(1): 42-51. https://doi.org/10.46505/IJBI.2020.2107.

[7] Prakash S. (2020a). Fish diversity of Semara Taal, a wetland of district Siddharthnagar (U.P.), India. International Journal of Fisheries and Aquatic Research. 5(2):07-09.

[8] Prakash S. (2020b). Conservation status of fishes reported from Semara Taal of District Siddharthnagar (U.P.). India. International Journal of Fauna and Biological Studies. 7(3): 21-24.

[9] Prakash S., Verma A.K., and Prakash S. (2015a). Limnological Studies of Alwara Lake of Kaushambi (U.P.). International Journal on Biological Sciences.6 (2): 141-144.

[10] Prakash S. andVerma A.K. (2015b). Studies on different fish genera in Alwara lake of Kaushambi. Bioherald: An International Journal of Biodiversity \& Environment. 5(1-2): 60-62.

[11] Prakash S., Verma A.K. and Prakash S. (2015c). Seasonal variation of Zooplankton and Zoobenthos Population in Alwara lake of District Kaushambi (UP) India. The Journal of Zoology Studies. 2(5):13-16.

[12] Prakash S. and Verma A.K. (2016a). Conservation status of fresh water fishes reported in Alwara Lake of District Kaushambi (U.P.). International Journal of Zoology Studies. 1(5): 32-35.

[13] Prakash S. and Verma A.K. (2016b). Marital fidelity and congregation of Indian sarus crane, Grus antigone antigone in and around Alwara lake of district Kaushambi (Uttar Pradesh), India. International Journal of Biological Research. 4 (1):10-13. https://doi.org/10.14419/ijbr.v4i1.5692.

[14] Prakash S. and Verma A.K. (2016c). Impact of awareness programme on growth and conservation of vulnerable avian species Grus antigone antigone in and around Alwara lake of District Kaushambi (Uttar Pradesh), India. The Journal of Zoology Studies. 3(2):1-5.

[15] Prakash S. and Verma A.K. (2016d). Studies on use of local medicinal flora in nest building by threatened bird, Grus antigone antigone in and around Alwara lake of district Kaushambi (U.P.), India. Journal of Applied Life Sciences International. 5(3):1-7. https://doi.org/ $10.9734 /$ ialsi/2016/26383

[16] Prakash S. and Verma A.K. (2017). IUCN Conservation Status of Fishes of Khanwari Pond of District Kaushambi (U.P.) Proceedings of The Zoological Society of India. 16 (1): 81-84.

[17] Prakash S. and Verma A.K. (2019a). Biodiversity Assessment of Khanwari Pond of District Kaushambi (U.P.). International Journal on Environmental Sciences. 10(1): 24-28.

[18] Prakash S. and Verma A.K. (2019b). Length-Weight Relationships and Condition Factors of Fresh Water Fishes of Baghel Taal of Bahraich (U.P.). Journal of Experimental Zoology, India. 22 (1): 343-345.

[19] Prakash S. and Verma A.K. (2019c). Comparative Analysis of Sarus Crane Population from 2012-2019 in and around Alwara Lake of District Kaushambi (U.P.), India. International Journal of Biological Innovations. 1(2): 36-39. https://doi.org/10.46505/IJBI.2019.1201.

[20] Prakash S. and Srivastava S. (2019). Impact of Climate Change on Biodiversity: An Overview. International Journal of Biological Innovations. 1(2): 60-65. https://doi.org/10.46505/IJBI.2019.1205.

[21] Prakash S., Kumar A., Prakash S.and Mishra B.K. (2020). A Survey of Fish Fauna of Rapti River, Balrampur (U.P.), India. International Journal of Biological Innovations. 2(1): 76-81. https://doi.org/10.46505/IJBI.2020.2110.

[22] Ranjan, R. and Prakash, S. (2019). Seasonal Variation in Primary Productivity and Macrophytes of Baghel Taal. Iconic Research and Engineering Journal. 3 (6):210-215.

[23] Singh R. and Singh G. (2019). Species Diversity of Indian Aphids (Hemiptera: Aphididae). International Journal of Biological Innovations. 1(1): 23-29. https://doi.org/10.46505/IJBI.2019.1105.

[24] Verma A.K. (2016a). Biodiversity: Its Different Levels and Values. International Journal on Environmental Sciences. 7(2): 143-145.

[25] Verma A.K. (2016b). Hydrobiological Studies of Muntjibpur Pond of Allahabad (U.P.). International Journal on Agricultural Sciences.7 (2): 164166.

[26] Verma A.K. (2016c).Dominancy of Cypriniformes fishes in Alwara Lake of District Kaushambi (U.P.). International Journal on Agricultural Sciences. 7 (1): 89-91.

[27] Verma A.K. (2016d). Distribution and Conservation Status of Catfishes in Alwara lake of District Kaushambi (U.P.). International Journal on Environmental Sciences. 7 (1):72-75.

[28] Verma A.K. (2016e). A Preliminary Survey of Fresh Water Fishes in Muntjibpur Pond of Allahabad (U.P.). Indian Journal of Biology. 3(2): 99101. https://doi.org/10.21088/ijb.2394.1391.3216.2

[29] Verma A.K. (2017a). Multiple effects of Unsustainable Agriculture. International Journal on Agricultural Sciences. 8(1): 24-26.

[30] Verma A.K. (2017b). Genetic Diversity as Buffer in Biodiversity. Indian Journal of Biology. 4(1):61-63.

[31] Verma A.K. (2017c). Necessity of Ecological Balance for Widespread Biodiversity. Indian Journal of Biology. 4(2):158-160.

[32] Verma A.K. (2017d). A study on ichthyo-diversity of Muntjibpur Pond of Allahabad (U.P.). Flora and Fauna. 23(1): 220-224. https://doi.org/10.33451/florafauna.v23i1pp220-224.

[33] Verma A.K. (2017e). Distribution and Conservation Status of Fishes reported from Muntjibpur Pond of Allahabad (U.P.): International Journal of Scientific World. 5(1):50-53. https://doi.org/10.14419/ijsw.v5i1.7162.

[34] Verma A.K. (2018a). Unsustainable Agriculture, Environmental Ethics and Ecological Balance. HortFlora Research Spectrum. 7 (3): $239-241$.

[35] Verma A.K. (2018b). Ecological Balance: An Indispensable Need for Human Survival. Journal of Experimental Zoology India. 21 (1): $407-409$.

[36] Verma A.K. (2018c). A Biodiversity Survey of Muntjibpur Pond of District Allahabad (U.P.). International Journal on Environmental Sciences. 9(1): 56-59. 
[37] Verma A.K. (2018d). Positive correlation between Indian Sarus Crane and Agriculture. Journal of Experimental Zoology India. 21 (2): $801-803$.

[38] Verma A.K. (2019a). Biodiversity of Higher Chordates at Khanwari village of Kaushambi (U.P.). International Journal of Fauna and Biological Studies. 6(3): 48-50

[39] Verma A.K. (2019b). Studies of Hydrobiological Properties of Balapur Pond of Prayagraj (U.P.). Hortflora Research Spectrum. 8(1): 9-11.

[40] Verma A.K. (2019c). A Study of Fish Distribution in Balapur Pond of Prayagraj (U.P.). InternationalJournal on Biological Sciences. 10(1): 7-10.

[41] Verma A.K. (2020). Conservation status of Anamniotes reported from Balapur Pond of District Prayagraj (U.P.). Uttar Pradesh Journal of Zoology. 61(6):42-46.

[42] Verma A.K., Prakash S. and Kumar S. (2015). Status and Ecology of Indian Sarus Crane, Grus antigone antigone in and around the Alwara Lake of District Kaushambi (U.P.). International Journal on Environmental Sciences. 6(2): 331-335.

[43] Verma A.K. and Prakash S. (2016a). Fish biodiversity of Alwara Lake of District Kaushambi, Uttar Pradesh, India. Research Journal of Animal, Veterinary and Fishery Sciences. 4(4): 5-9.

[44] Verma A.K., Kumar S. and Prakash S. (2016b). Seasonal Correlation between physico chemical factors and phytoplankton density in Alwara taa of Kaushambi, U. P., India. International Research Journal of Biological Sciences. 5(3):40-45.

[45] Verma A.K. and Prakash S. (2016c). Population dynamics of Indian Sarus Crane, Grus antigone antigone (Linnaeus, 1758) in and around Alwara lake of Kaushambi district (Uttar Pradesh), India. International Journal of Biological Research. 4 (2). 206-210. https://doi.org/10.14419/ijbr.v4i1.5692.

[46] Verma A.K. and Prakash S. (2016d). Selective behaviour of Indian Sarus Crane in choosing plant species for nest construction in and around Alwara lake of district Kaushambi (U.P.), India. International Journal of Zoology and Research. 6 (3):1-6.

[47] Verma A.K. and Prakash S. (2017a). Fish Biodiversity of Khanwari Pond of district Kaushambi (U. P.), India. The Journal of Zoology Studies. 4(1): 37-40.

[48] Verma A.K. and Prakash S.(2017b). Dominancy of Cat fishes in Khanwari Pond of District Kaushambi (U. P.). Life Science Bulletin. $14(1)$ : 85-87.

[49] Verma A.K. and Prakash S. (2018a). Qualitative and Quantitive Analysis of Macrozoobenthos of Baghel Taal, A Wetland of U.P. Indian Journal of Biology. 5(2):127-130. DOI: http://dx.doi.org/10.21088/ijb.2394.1391.5218.3

[50] Verma A.K. and Prakash S. (2018b). A study on the population scenario of Indian Sarus crane (Grus antigone antigone) in and around Alwara Lake of District Kaushambi (U.P.), India. Asian Journal of Biology. 5 (1): 1-8. https://doi.org/10.9734/AJOB/2018/38911.

[51] Verma A.K. and Prakash S. (2018c). Sustainable Conservation and Management of Indian Sarus crane (Grus antigone antigone) in and around Alwara Lake of District Kaushambi (U.P.), India. Indian Journal of Biology. 5(2): 150-153. http://dx.doi.org/10.21088/ijb.2394.1391.5218.7

[52] Verma A.K. and Prakash S. (2019). Sustainable Increase in the Number of Indian Sarus crane in and around Alwara Lake of District Kaushambi (U.P.), India. International Journal of Zoology Studies. 4(3): 30-33.

[53] Verma A.K. and Prakash S. (2020). Limnological Studies of Semara Taal, A wetland of District Siddharthnagar (U. P.), India. Journal of Fisheries and Life Sciences. 5 (1): 15-19.

[54] Wahied K.B. and Neelam S. (2020). Decline of House Sparrow and Common Myna Population in Doda Region of Jammu and Kashmir, India. In ternational Journal of Biological Innovations. 2(1): 20-24. https://doi.org/10.46505/IJBI.2020.2103.

[55] Yasmeen S. and Dugaje P. (2020). Holistic Survey on predatory Ladybird beetle diversity at selected regions of Nashik District (Maharashtra), India. International Journal of Biological Innovations. 2(1): 52-62. https://doi.org/10.46505/IJBI.2020.2108. 